After establishing the existence of the eight illegal practices described above, the court experienced little difficulty in finding a conspiracy under Section $x$ of the Sherman Act. ${ }^{84}$ Because of the criminal nature of the case Judge Knox felt it advisable to make a sharp distinction between Section $\mathrm{I}$ and Section 2 of the Act, and conviction on three counts laid under Section 2 followed. Discussion of the problems raised by these findings is beyond the scope of this paper. ${ }^{85}$ It is believed that the particular restraints of trade already discussed represent significant, though not unexpected, developments in a rapidly changing field of the law. Generally speaking, the price fixing powers of the patentee have been further restricted, and at the same time the court has recognized that a patent represents only a limited grant of monopoly power which by no means forecloses the current judicial policy of enforcing competition wherever it is possible to do so.

\title{
ACCEPTANCE AND REJECTION IN CONTRACTS BY CORRESPONDENCE
}

In a recent Court of Claims case, Dick v. United States, ${ }^{1}$ the court limited the "rule" that a letter of acceptance is "effective" when mailed." The Coast Guard opened negotiation solely with the plaintiff for the purchase of two sets of new type propellers to be used on icebreaking vessels. By mistake, the plaintiff figured his bid on the basis of one set of propellers instead of two. After an exchange of communications, the Coast Guard mailed an offer to purchase the propellers. Shortly after depositing his letter of acceptance in the mail the plaintiff discovered his mistake, and telegraphed a rejection of the offer, which arrived before the letter of acceptance. Relying on a subsequent agreement with the Coast Guard contracting officer, the plaintiff manufactured and delivered the propellers. The government paid for only one set of propellers, claiming that the contracting officer had no authority to modify the contract formed when the letter of acceptance was mailed. In the plaintiff's action seeking payment for the

${ }^{84}$ Relying on Interstate Circuit v. United States, 306 U.S. 208 (1939).

${ }^{85}$ It may be mentioned in passing that all parties placed considerable emphasis on the question of whether the pooled patents were competing or infringing, GE taking the position that they were infringing patents and that therefore some sort of pooling was essential for proper exploitation. If the patents were competing the pool would clearly be condemned by Standard Oil Co. (Indiana) v. United States, 283 U.S. I63, I74 (I93I), since Krupp and GE were dominant firms. Judge Knox found it unnecessary to decide the question inasmuch as the means of exploitation were illegal in any event. Moreover, United States v. Line Material Co., 333 U.S. 287 (1948), casts great doubt over the validity of GE's line of argument, though the problem is admittedly a highly complex one.

$\therefore 82$ F. Supp. 326 (Ct. Cl., I949).

2 It is generally considered that Adams v. Lindsell, r Barn. \& Ald. 68I (K.B., I8I8) established the traditional rule. Compare McCulloch v. Eagle Insurance Co., I Pick. (Mass.) 278 (1822). For a discussion of the early development of the traditional rule in England which was finally settled in Household Fire \& Carriage Accident Insurance Co. v. Grant, 4 Ex. D. 216 ( 1879 ), see Contract by Letter, 7 Am. L. Rev. 433 (1873). For American cases concerning the traditional rule see Williston, Contracts $\$ 81$ (I937). 
extra set of propellers, the government's demurrer, based upon the traditional "letter of acceptance" rule, was overruled by a majority of the court. ${ }^{3}$

Had the court realized that the "letter of acceptance" rule is actually at least three rules covering at least three different problems it could have availed itself of an opportunity to clarify this confused area of the law. The three rules are: first, the offeror cannot revoke his offer after the offeree's letter of acceptance is deposited in the mail; second, the risk of loss or delay is placed on the person who has chosen the agency of communication; third, the offeree cannot reject the offer after his acceptance has been mailed, even though the rejection arrives ahead of the acceptance. 4 However, to recognize that there are in fact three rules is not enough. Clarification depends also on an understanding of the proper rationale for each rule.

The traditional rule developed because the nineteenth-century English judges recognized that in contracts by correspondence there was a need for limiting the power of the offeror to revoke his offer. ${ }^{5}$ Somehow the offeree must be given a "dependable basis for his decision." Permitting the offeror to revoke after the offeree has done everything he could possibly do to communicate his acceptance by depositing the letter in the mail put the offeree in a precarious position. By relying on the finality of his act, the offeree might be hurt in ways dificult to prove-for instance, he might neglect other business opportunities.

The easiest and simplest way to protect the offeree in such a situation would be an outright acceptance of the firm offer principle. However, the entrenched notions of consideration have prevented the use of this principle. ${ }^{7}$ Indeed, the deposit of the letter of acceptance is probably not such a substantial change of position as to satisfy the requirements of the principle stated in Section go of the Restatement of Coniracts. ${ }^{8}$ Because the courts could not protect the offeree by establishing a firm offer principle, they made a more sweeping generalization. They found that a contract was formed when the letter of acceptance was mailed rather than when it was received. Thus, the sympathy of the courts for the vulnerable position of the offeree who had mailed his letter of acceptance led them to violate the common-sense notion of the nature of a communication.

Once it was established that a contract was made when the letter of accept-

3 Judge Madden dissented upholding the traditional "letter of acceptance" rule.

4 Nussbaum, Comparative Aspects of the Anglo-American Offer-and-Acceptance Doctrine, 36 Col. L. Rev. 920 (1936); Sharp, Promissory Liability I, 7 Univ. Chi. L. Rev. I, II-I 2 (I939). A recognition of the need to break down the rigid rule is seen in Rest., Contracts $\$ 39$ (1932).

5 In particular, Mellish's opinion in In re Imperial Land Co. of Marseilles, Harris' Case, L.R. 7 Ch. App. $5^{87}$ ( 1872 ), set forth the mercantile problems of permitting the offeror to revoke after the mailing of the letter of acceptance by the offeree. The case of Henthorn $v$. Fraser, [1892] $2 \mathrm{Ch} .27$, supported this decision. Supporting the view that the "letter of acceptance" rule grew out of the need to protect the offeree is the fact that the related problems have been treated differently in continental countries where the firm offer principle was accepted. Nussbaum, op. cit. supra note 4 .

'Nussbaum, op. cit. supra note 4 , at 925 .

7. Cooke v. Okley, 3 Term. R. 653 (K.B., r79o); Dickinson v. Dodds, 2 Ch. D. 463 (1876).

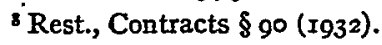


ance was mailed, it was an easy and inevitable step to overgeneralize by applying this rule in the two related situations. Thus, there is a little authority for a satellite rule that a rejection which arrives before a letter of acceptance may be ineffective because a contract has been formed by mailing the letter of acceptance before the receipt of the "rejection." The same overgeneralization is manifested in imposing upon the offeror the risk of the loss or delay of the letter of acceptance. Even though the offeror may never receive the letter of acceptance, may consider the silence a rejection, and as a result may deal with other parties, he is still liable to the offeree if he cannot perform.

Another justification for the "letter of acceptance" rule depends on a fiction that the post office is the agent of the offeror. ${ }^{\mathrm{xo}}$ This is so, it is said, because "when a letter [is] deposited in the mails it [is] beyond the control of the person mailing it." ${ }^{I x}$ Since the offeree loses dominion over his letter of acceptance when he mails it, the contract is formed at that time; it is as if he had actually given the letter to the offeror. Thus the agency approach ostensibly avoids the pitfall of considering the letter of acceptance a "communication" before it is received. The result under the agency theory is, however, also an overgeneralization which may cover the related situations. Once the letter of acceptance is given to the agent post office, a rejection which is received by the principal-offeror before the acceptance is ineffective because too late..$^{x_{2}}$ Similarly, any risk of loss or delay caused by the offeror's agent (the post office) is placed on the offeror.

The unhappy results of these approaches to contracts by correspondence can be avoided by the formulation of three separate rules each determined by a clear appraisal of the individual situations involved. The traditional rule - that a letter of acceptance is effective when mailed-is nothing more than a recognition that in contracts by correspondence the offeree deserves the protection afforded by limiting the offeror's power to revoke. Unfortunately, in the present state of contract law this desirable result cannot be achieved directly by the acceptance of the firm offer principle. ${ }^{\mathrm{x}}$ The "letter of acceptance" rule accom-

9 Guardian National Bank v. Huntington State Bank, 206 Ind. 185 , 187 N.E. 388 (I933); Trader's National Bank v. First National Bank, I42 Tenn. 229, 2x7 S.W. 977 (I920). For a discussion of this problem see Annotation, 9 A.I.R. 386 (1920); Annotation, 92 A.L.R. Io62 (1934). Compare Rest., Contracts $\$ 39$ (I932).

10 This question-begging argument using the agency theory has been criticized by writers: Communication of Acceptance between Parties at a Distance, I5 Corn. L.Q. 273 (1930). Other explanations are offered for the traditional rule besides the two mentioned in this paper in $x$ Page, Contracts $\& 208$ (Ig20); Anson, Contracts $\$ \S 39-42$ (Corbin's ed. 1930); The Completion of a Contract by Posting of Acceptance, I3 Mich. L. Rev. 672 (1915).

II Dick v. United States, 82 F. Supp. 326, 329 (Ct. Cl., 1949).

72 In the instant case the court approached the problem according to the postoffice-agency theory. However, it found that postal regulations-39 Code Fed. Reg. $\$ \S$ I0.9, I0.I0, I6.I7 (r938) - now permitted the sender to retrieve his letter from the post office. The court reasoned, therefore, that the post office was now the agent of the offeree, and that a timely rejection was effective.

${ }^{13}$ Two elements in the theory supporting the firm offer may be suggested. First, there is a recognition that the ordinary offer implies in fact a promise that it shall be firm for a reasonable length of time, in the absence of a stated length of time. Second, there is a risk of reliance 
plishes the same result at the expense of a common-sense definition of a communication. The protection of the offeree is worth this price.

But the attack on communication notions need not continue where a rejection is involved. If the reason for the traditional rule is to prevent the offeror from revoking, it has no application to the problem of the offeree's power to reject before his letter of acceptance has reached the offeror. As a practical matter, the offeror is not going to act anyway until he gets the letter of acceptance. ${ }^{{ }^{4}}$ If the offeree does reject in time, the offeror's expectations are not affected, for he does not even know about the letter of acceptance. Consequently, the rejection should be given its usual effect as a communication when received before the letter of acceptance. No other rule is sensible. To prohibit the offeree from nullifying the effect of a letter of acceptance mailed but not yet received is to transform what was intended to be a boon into a boomerang.

What should be the rule for placing the risk of loss or delay? The pat formula deduced from the "letter of acceptance" rule places all the risk of loss or delay on the offeror because he chose the agency of communication. As Professor Sharp points out, this is "comparable to a rule that everyone who drives a car takes the risk of all accidents which the car may occasion." ${ }^{5}$ Many reasons have been offered for placing the entire loss on one party or the other, ${ }^{16}$ but there seems to be general agreement that in no real sense is either party at fault. ${ }^{17}$ In addition, the loss or delay cannot be thought to be a risk for which the parties contracted, such as a fluctuation in price. ${ }^{18}$ It would seem reasonable, therefore, subject to familiar rules about restitution, to provide only for the division of reliance damages. ${ }^{\text {I9 }}$

in conduct on the part of the offeree, which may be difficult to prove. For a discussion of risk of reliance see Promissory Obligations Based on Past Benefits or Other Moral Consideration, 7 Univ. Chi. L. Rev. 124, 133-136 (1939). This notion of risk of reliance would seem to apply to all business offers. So one result of a recognition of risk of reliance in contracts by correspondence might be a more general acceptance of the firm offer principle in other business promises. Sharp, Pacta Sunt Servanda, 4I Col. L. Rev. 783, 793-794 (I94I).

${ }^{4}$ Pollock, The Principles of Contracts 34 (Ioth. ed. 1936).

Is Sharp, Promissory Liability I, 7 Univ. Chi. L. Rev. I, 6 (I939).

${ }^{56}$ Compare Langdell, Summary of the Law of Contracts 20-21 (2d. ed. I880), with Llewellyn, Our Case-Law of Contract: Offer and Acceptance II, 48 Yale L.J. 779, 795 (I939).

${ }_{17}$ "Neither is at fault, but one must suffer loss as a result of the negligence of the agency of communication, upon whom should the loss fall?" Stimson, Effective Time of Acceptance, 23 Minn. L. Rev. 776, 777 (I939). If one of the parties is at fault, that would be a reason for placing the loss on his shoulders.

${ }^{18}$ Again, if the parties do expressly assume the risk of loss or delay in the contract, that eliminates the suggested solution.

I9 Compare Law Reform [Frustrated Contracts] Act, 6 \& 7 Geo. VI, c. 40 (rg43). Since neither party wants the expense of law suits, a desirable method of cutting down insecurity and loss in communication would be through the use of the registered letter with the return receipt attached. If the offeree does not get his return receipt back within a short time he ought to take steps to inquire into the whereabouts of the letter of acceptance. This also would cut 
Although the present rules are unsatisfactory, they do at least protect the offeree from the offeror's power to revoke. The Dick case may imperil this protection. By rejecting the contention that the post office is the agent of the offeror, the court destroyed one common basis for the "letter of acceptance" rule. ${ }^{20}$ If the "letter of acceptance" rule is set aside, the rejection situation can then be handled in a normal manner. The problem of how to allocate the risk of loss or delay in contracts by correspondence would confront the courts anew. At its best, the Dick case may perform the service of calling attention to the need for a firm offer principle.

\section{FURTHER RETREAT FROM THE POLEMIS DOCTRINE}

The House of Lords appears to have hammered another nail into the coffin of the so-called English or "Polemis" rule of proximate cause. Not long after In re Polemis ${ }^{\mathrm{x}}$ established the original rule, the high court initiated a course of qualification and restriction which has now culminated in the recent case of Monarch S.S. Co. v. A/B Karlshamns Oljefabriker. ${ }^{2}$ Thus the House of Lords has raised anew the perplexing question of the extent of liability for negligent acts.

In the Monarch case appellant had contracted to ship a cargo of beans to Sweden prior to World War II. Due to various defects in the vessel which caused her to be unseaworthy, she was still enroute when war broke out. By Admiralty orders the ship was diverted to Scotland where the cargo was transhipped aboard neutral vessels to Sweden. The court allowed the cost of the shipment as damages, basing the award on the principle of "reasonable contemplation," which, apparently, will now replace the "Polemis" rule in the field of torts.

The English retreat from the Polemis doctrine began with Liesbosch, Dredger v. Edison S.S. ${ }^{3}$ There the plaintiff' dredger was moored in a harbor when the defendants' steamship fouled the moorings and carried her out to sea, where she sank and was lost. The plaintiffs had invested all their liquid assets in a contract undertaking; and, unable to buy their own dredger, they were forced to pay a high rate of rent on another which was much more expensive to operate. The plaintiffs included in their claim for damages the loss due to the work stoppage between the date of the sinking and the hire of the dredger, the extra expense in renting, and the added expense in operating the rented dredger. Since the de-

down any fraud which the offeror might undertake. Since the offeror signs the return receipt when he receives the letter of acceptance, he could hardly claim later that he never received the communication.

20 There is, however, no reason to think that a well-advised court will permit the offeror to revoke after the letter of acceptance has been mailed.

[ [rg2r] 3 K.B. 560 .

2 [1949] I All E.R. I. See Bourhill v. Young, [I943] A.C. Iro; Liesbosch, Dredger v. Edison S.S., [I933] A.C. 449; Salmond, Torts I3I-I37 (I0th ed. I945).

3 [r933] A.C. 449 . 